Romanticism on the Net

An open access journal devoted to British Romantic literature

Ro Romanticism on the Net

\title{
"Furnace-smoke ... wrapt him round": Industrial Hinduism and Global Empire in The Curse of Kehama and Sir Thomas More
}

\section{Joseph DeFalco Lamperez}

Numéro 68-69, spring-fall 2017

Robert Southey

URI : https://id.erudit.org/iderudit/1070622ar

DOI : https://doi.org/10.7202/1070622ar

Aller au sommaire du numéro

Éditeur(s)

Université de Montréal

ISSN

2563-2582 (numérique)

Découvrir la revue

Citer cet article

DeFalco Lamperez, J. (2017). "Furnace-smoke ... wrapt him round”: Industrial Hinduism and Global Empire in The Curse of Kehama and Sir Thomas More. Romanticism on the Net, (68-69). https://doi.org/10.7202/1070622ar
Résumé de l'article

My essay claims that Robert Southey uses Hinduism to fashion a poetics of Romantic-era technology in The Curse of Kehama (1810). In his neglected Sir Thomas More; or, Colloquies on the Progress and Prospects of Society (1829), Southey compares the manufacturing system to Indian theology and ritual, a metaphor that relativizes religion and technology while implying that the Industrial Revolution amounts to a new breed of religious network. Southey next likens the emergent world order made possible by such technologies to the cosmic ambitions of Kehama, his own Indian tyrant-cum-demigod. The Colloquies thus suggests an allegorical reading of The Curse of Kehama, whereby this tale of a king bent on cosmic rule simultaneously explores how technological and imperial networks intertwine. Accordingly, I draw from metaphor theory to read the earlier Kehama as a repository of veiled comparisons and displacements through which Southey glimpses the magnitude of the Industrial Revolution. Just as Indian wealth propels the techno-imperial enterprise described in the Colloquies, Kehama's paganism supplies the raw discursive material through which Southey fashions a poetics of manufacturing. Read alongside the Colloquies, Kehama aestheticizes the connection between imperial and technological systems, expresses the imaginative significance of twinned manufacturing novelties-the steam engine and coke smelting-and concretizes the opaque moral and poetic properties attaching to industrial power by depicting it in reference to the minutiae of Hindu religion so far as Southey understood it.
Ce document est protégé par la loi sur le droit d'auteur. L'utilisation des services d'Érudit (y compris la reproduction) est assujettie à sa politique d'utilisation que vous pouvez consulter en ligne.

https://apropos.erudit.org/fr/usagers/politique-dutilisation/ 


\title{
Ron
}

Romanticism on the Net

\section{"Furnace-smoke ... wrapt him round": Industrial Hinduism and Global Empire in The Curse of Kehama and Sir Thomas More}

Joseph DeFalco Lamperez

Xavier University of Louisiana

\begin{abstract}
My essay claims that Robert Southey uses Hinduism to fashion a poetics of Romantic-era technology in The Curse of Kehama (1810). In his neglected Sir Thomas More; or, Colloquies on the Progress and Prospects of Society (1829), Southey compares the manufacturing system to Indian theology and ritual, a metaphor that relativizes religion and technology while implying that the Industrial Revolution amounts to a new breed of religious network. Southey next likens the emergent world order made possible by such technologies to the cosmic ambitions of Kehama, his own Indian tyrant-cum-demigod. The Colloquies thus suggests an allegorical reading of The Curse of Kehama, whereby this tale of a king bent on cosmic rule simultaneously explores how technological and imperial networks intertwine. Accordingly, I draw from metaphor theory to read the earlier Kehama as a repository of veiled comparisons and displacements through which Southey glimpses the magnitude of the Industrial Revolution. Just as Indian wealth propels the techno-imperial enterprise described in the Colloquies, Kehama's paganism supplies the raw discursive material through which Southey fashions a poetics of manufacturing. Read alongside the Colloquies, Kehama aestheticizes the connection between imperial and technological systems, expresses the imaginative significance of twinned manufacturing novelties - the steam engine and coke smelting-and concretizes the opaque moral and poetic properties attaching to industrial power by depicting it in reference to the minutiae of Hindu religion so far as Southey understood it.
\end{abstract}

\section{Biographical Note}

Joseph DeFalco Lamperez is a visiting Assistant Professor at Xavier University of Louisiana. His dissertation, "The Idol and the Machine: Hinduism and Technology in the Romantic Imagination," shows that the Industrial Revolution was imagined through descriptions of Indian religion, a metaphor allowing writers to envision a world order reliant on new technologies and pagan social forms. His research interests include Romantic-era imperialism, subaltern studies, technology, religion, and urban studies. His work has appeared in Mosaic: An Interdisciplinary Critical Journal and Studies in Romanticism. 


\section{Romanticism on the Net \#68-69 (Spring-Fall 2017). Special issue on Robert Southey. Guest-edited by Tim Fulford (De Montfort University) and Matthew Sangster (University of Glasgow)}

1. Sir Thomas More; or, Colloquies on the Progress and Prospects of Society (1829) describes a series of conversations between a fictive poet named Montesinos and the ghost of the fabled statesman, who visits Earth to discuss events of the Regency era with a thoughtful witness of equal intellectual rank. The text is generically promiscuous. While at times it stresses the gothic traits of a story premised on ghostly visitation (anticipating Edgar Allan Poe, Montesinos writes that "it was during that melancholy November" while he was "sitting alone, at evening, in my library" [1] that he first meets the spectre of Sir Thomas), at others it lapses into the rhetoric of the travel memoir (strolling through Keswick, the poet notes later that "the lake lay like a mirror, smooth and dark" while "the tops of the mountains, which had not been visible for many days, were clear and free from snow" [118]).

2. These generic experiments reflect Southey's attempt to craft new narrative forms capable of tracing how the crises of one epoch shed light on those of the next. The Regency era contrasts suggestively with More's own period of rebirth and reform because both bear witness to upheavals of British history: "I ... come ... to discourse with you," More admits, "concerning these portentous and monster-breeding times; for it is your lot, as it was mine, to live during one of the grand climacterics of the world" (18). More returns to this comparative historical method across several appearances. Urging Montesinos to "see in how many things the parallel between this age and mine holds good" (234), he makes no secret of his hope that,

By comparing the great operating causes in the age of the Reformation, and in this age of revolutions, going back to the former age, looking at things as I then beheld them, perceiving wherein I judged rightly, and wherein I erred, and tracing the progress of those causes which are now developing their tremendous power, you will derive instruction, which you are a fit person to receive and communicate. (STM 19)

Bygone religious upheavals clarify the political and technological revolutions of Southey's own time, which betray a commensurate power to destabilize. That Montesinos understands this relationship qualifies him to converse with More: "I come to you, rather than to any other person," the ghost explains, "because you have been led to meditate upon the ... changes whereby your age and mine are distinguished" (18).

3. Within this framework, conversations range more widely than chapter titles suggest. While these ensure that our pair will cover "Feudal Slavery," "The Prospects of Europe," and 


\section{Romanticism on the Net \#68-69 (Spring-Fall 2017). Special issue on Robert Southey. Guest-edited by Tim Fulford (De Montfort University) and Matthew Sangster (University of Glasgow)}

"Catholic Emancipation," over the course of fifteen meetings More and Montesinos also discuss the psychology of childhood, the merits of vegetarianism, variations of slavery across the globe, the enmity of the houses of York and Lancaster, enclosure, feudalism, monasteries, piracy, the Norman invasions, capital punishment, Edward VI, the advent of gunpowder, and a great deal more. Organizing this miscellany is the presumption that systems and institutions are any given era's primary actors, uniquely capable of impacting the tenor of collective life. Neither figure blames individuals or communities for the problems that they identify. Instead, as More says to Montesinos, "the fault lies in your institutions" (93), the problems in question ensuing from "a derangement of" any given "existing system" (97).

4. But while Colloquy VII: The Manufacturing System continues to explore how institutions produce collective life, More and Montesinos find little common ground as they address the legacies of the Reformation and the Industrial Revolution. Though they tend to focus on "points of sympathy and resemblance" (18) in each other's views-Montesinos remarks at one point that "when we understand each other, there is likely to be little difference between us" (49)the poet and his ghostly counterpart grow testy when debating how these movements intersect. While Adrian Wallbank's claim that their exchanges are "uniquely disputative" (172) overstates the space afforded to disagreement in most chapters, Colloquy VII plays out through one quarrel after the next, the pair frequently pausing to upbraid one another with uncharacteristic impatience ("Montesinos," More dryly observes at one point, "that reply is a rambling one" [STM 163]).

5. But this chapter is most distinguished by its radical historical revisionism, as ghost and poet link the Reformation, the Industrial Revolution, and Britain's nascent global empire in the following sequence. First, religious reform wipes out the myriad objects of Catholicism, stymying the human need to genuflect before guiding symbols of communal life. This neglected instinct then finds expression through an industrial object network of engines and machines, which supplants Catholic crucifixes and rosaries to establish itself as the primary symbol system of British society. Propelled by the imaginative needs of the British populace, this technological network next gives rise to a growing empire premised on trade and machinery until an emergent world order finally requires diplomatic linkages to pagan societies in turn. If what John Lardas Modern calls the "habitus of technomodernity" (186) describes a secular 


\section{Romanticism on the Net \#68-69 (Spring-Fall 2017). Special issue on Robert Southey. Guest-edited by Tim Fulford (De Montfort University) and Matthew Sangster (University of Glasgow)}

social order that is "pervasively haunted by its very effort to disenchant the world" (Stolow 9), More and Montesinos define the early industrial era in reference to the tenacious paganismsCatholic, technological, Indian - that it sets out to repress.

6. When Montesinos finally predicts that British empire will soon encircle the globe, More compares this vision to the vainglorious designs of the Indian rajah Kehama, a coy allusion that figures Southey's own tyrant-cum-demigod as a metaphor signifying the pact between industrial and imperial power. In addition to the breakneck historicizing and our duo's fractious tone, More and Montesinos thus rely on a symbolic mode of description. In fact this mention of Kehama gives way to several comparisons that describe industrial social forms in reference to Indian religion, a discursive reflex that I propose to extend to the whole of The Curse of Kehama (1810). When Montesinos explains how a "vagrant, brutalized population" (STM 96) newly formed in More's era becomes a fully-fledged social class in Montesinos's, he borrows a reference from India: "With you they were, as you have called them, outcasts: with us, to borrow an illustration from a foreign institution, they have become a cast" (97). Elsewhere Montesinos compares wealth produced by the manufacturing system to an Indian god: "There is a nation of warriors in Hindostan who call their deity All-Steel. Commercial nations, if they acknowledged the deity whom they serve, might call him All-Gold. And if the sum of their sacrifices were compared, Mammon would be found a more merciless fiend than Moloch" (169). Describing how market forces and government policy intertwine to destabilize the national economy, More explains that "In proportion, then, as wealth is created in one quarter, it is, as far as the operation extends, annihilated in another. This is like your Hindoo mythology; but in part only,..for while we have the Creator and the Destroyer here at work, I miss the Preserving Power!" (188) More also insists that "your manufacturers and artificers have their secrets at this day, as the priests of Greece and Egypt had theirs" (203), while Montesinos laments industrial blight "from the largest of Mammon's temples down to the poorest hovel" (174). Wherever language comes up short in the face of industrial novelty, be it social, architectural, technological, or economic, Southey references "the religion of the Hindoos" (Kehama vii) or paganism more generally. When More complains that industry is "a wen, a fungous excrescence on the body politic" and his friend retorts that "happily, this is but a metaphor" (STM 171), he offhandedly names the discursive form that presides across their entire conversation. 


\section{Romanticism on the Net \#68-69 (Spring-Fall 2017). Special issue on Robert Southey. Guest-edited by Tim Fulford (De Montfort University) and Matthew Sangster (University of Glasgow)}

7. We should not be surprised that this trope prevails in a text describing how manufacturing "transformed in the space of scarce two lifetimes the life of Western man, the nature of his society, and his relationship to other peoples of the world" (Landes 1). Since one "function of metaphor ... is to extend language ... wherever something new is invented requiring a name" (Henle 96), this discursive form is well matched to its mechanical counterpart: As More intones elsewhere in Colloquy VII, "There are new things under the sun,..new miseries,..new enormities,..this portentous age produces them" (STM 167). At least one scholar has noted that Romantic authors "resort to metaphor to fill [the] semantic void" (Ricoeur, Rule 18) opened by the Industrial Revolution. But Steven Marcus contends that metaphors fell short in this respect, writing that "the astonishing newness of this system" (49) faced writers of the era with an "inadequacy of the conceptual field" (22). While nineteenth-century responses to technology include "allusions to classical mythology ... references to and analogies with ancient history ... volcanoes ... earthquakes ... stormclouds, whirlpools ... vortexes ... vast hives and swarms of industrious bees," each apparently "fail[s] to catch up or correspond to the literal and figurative alterations of form and substance, of nature and humanity" (22-23) arising from new engines and techniques.

8. But Southey's blend of idol and machine suggests that this metaphor gained greater poetic traction than Marcus realizes. Thus I claim that The Curse of Kehama, Southey's epic poem describing religion in India, also covertly signifies industrial processes. By figuring "steam engines and cotton mills" as the analogue of "polytheism and idolatry" and Kehama himself as a sign of techno-imperial ambition, the Colloquies implies that this earlier text expresses the poetic identity of the manufacturing system by imagining it through descriptions of Hinduism. Accordingly, I read Kehama as a repository of veiled comparisons and displacements through which Southey explores the theological, moral, and aesthetic implications of the technological revolution. In my reading, the vision of pagan machinery emerging from Southey's blend of religion and technology creates new meanings and sensibilities, or what Paul Ricoeur calls "a new semantic congruence" ("Process" 240). In other words, the fusion of Indian religion and British engineering produces a novel gestalt, blending elements of both domains but resolvable into neither. This "irreducible intellectual operation" (Ricoeur, Rule 101) is produced from what I. A. Richards calls "the co-presence of vehicle and tenor" (55), the constitutive parts of metaphor from whose interplay new meanings emerge. That the Colloquies describes 


\section{Romanticism on the Net \#68-69 (Spring-Fall 2017). Special issue on Robert Southey. Guest-edited by Tim Fulford (De Montfort University) and Matthew Sangster (University of Glasgow)}

engineering in reference to idolatry even while relativizing religious and technological systems licenses my reading of Kehama as one of the era's central expressions of Hinduism and the Industrial Revolution alike.

I.

9. The meeting that Southey subtitles "The Manufacturing System" begins, confusingly enough, with a discussion of religion, as More laments that the Reformation has "lowered the standard of devotion" and "lessened the influence of religion ... among all classes" (STM 154). But privileging "spirit above matter, belief above ritual ... and inward contemplation above 'mere' outward action" (Houtman and Meyer 1), Montesinos counters by asking: "How can that Reformation have lowered devotion which has 'withdrawn' it from stocks and stones, relics, beads, girdles, and scapularies, polytheism and idolatry?" (STM 154). While he thus suggests "an understanding of religion in terms ... of an interior spiritual experience" (Houtman and Meyer 1), poet and ghost together reflect "the constant pendulum between what one says and what one does in religion" (Stroumsa 8). With the advent of colonialism, however, the accent began to fall on observable expressions and behaviors: "new knowledge of the diverse religious practices around the world entail[ed] the urgent need to redefine religion as a universal phenomenon with a strong emphasis on ritual, rather than on beliefs" (3).

10. The scope of this colonial-era, ethnographic emphasis on ritual as a diagnostic tool capable of describing new social forms extends in Colloquy VII to Britain itself, as More stresses the role of symbols in collective life. Recalling how Catholicism shaped British identity before the Reformation, More insists that "religion may be neglected in Roman Catholic countries, but it cannot be forgotten; it is impressed upon the sense of the people; travel where they will its symbols are perpetually presented to them" (STM 156), an observation echoing the premise of symbolic anthropology. More implies that symbol systems help produce communal identity, anticipating Clifford Geertz's claim that "symbols function to synthesize a people's ethos ... and their world view" (89). Catholicism in the Colloquies exemplifies the power of symbols over the shared imagination: People "see the Cross or the Crucifix not in towns and villages alone, but in lonely places and by the way-side. The open shrine invites them to an act of 


\section{Romanticism on the Net \#68-69 (Spring-Fall 2017). Special issue on Robert Southey. Guest-edited by Tim Fulford (De Montfort University) and Matthew Sangster (University of Glasgow)}

devotion as wholesome as it is transitory; and the vesper bell unites them with all their brethren wherever dispersed" (STM 156).

11. Having shown that symbols inspire what Geertz calls "the social and psychological processes which shape public behavior" (89), Southey widens the scope of this unlikely dialogue. Religions with rich material traditions do not merely remind observers of their religious commitments; they also harness pagan habits latent within the human imagination. Where Catholicism is "publicly and practically recognized," More observes,

Mammon can never acquire that undisputed and acknowledged supremacy which he seems to have obtained in commercial countries, and in no country more decidedly than in this. The spirit, which built and endowed monasteries is gone. Are you one of those persons who think it has been superseded for the better by that which erects steam engines and cotton mills? (STM 158)

Symbol systems here exemplify what Geertz calls "the essence of religious action" (112) while rituals act as a measure of the religious commitment of a given society. Within these parameters, the Colloquies implies, an era of new devices and techniques will appear as a form of newfangled idolatry. Southey thus relativizes religion and technology: As Saree Makdisi notices, in Colloquy VII "steam and steel represent the modern-day equivalent of ... primitive wood and stone idols" (182). If "ethnology replace[d] theology on the front stage of the study of religion" (Stroumsa 9) in the wake of encounters with pagan societies, so that "idolatry was the main religious category through which new religions could be understood" (21), Southey suggests that industrialism itself may qualify as a new breed of religious network.

12. Far from destroying paganism, religious reform thus widens its arena of expression, whetting an appetite for new machinery that fuels a nascent world order bounded at its imperial and domestic margins by pagan objects and industrial devices, respectively. These networks then begin to call to mind one another as manufacturing facilitates colonialism, even while accords with Hindus continually replenish the coffers of the national treasury and the East India Company: "If England had not been enabled by the use of steam-engines to send out every year myriads of brave men, and millions of specie," Montesinos wonders, "what had Europe, and what had England itself been now? This inestimable benefit we have seen and felt" (STM 159). Once "steam and steel" become the engineering analogue of "primitive wood and stone idols," 


\section{Romanticism on the Net \#68-69 (Spring-Fall 2017). Special issue on Robert Southey. Guest-edited by Tim Fulford (De Montfort University) and Matthew Sangster (University of Glasgow)}

the empire that they make possible appears fueled by a kind of mechanistic expression of "polytheism and idolatry." Across this exchange More and Montesinos thus conflate paganism with what Bernard Steigler calls "planetary industrial technics - the systematic and global exploitation of resources, which implies a worldwide economic, political, cultural, social and military dependence" (31).

13. Only after suggesting that the Reformation builds toward a world order fueled by pagan technology does Montesinos find himself likened to Kehama. "From the consequences of that skill in machinery which the manufacturing system alone could have produced," the poet muses, "we may expect ultimately to obtain the greatest advantages at the least expense of human labor," meaning that the Industrial Revolution will one day render the world perfectly susceptible to British exploitation. More's reply is no less provocative, in its own way, than this grandiose prediction:

Sir Poet, travel not so hastily in your speculations! There is a wide gulph between you and that point, and it is not to be crost by one of these flying leaps in seven-leagued boots. Neither are you to expect that, when you reach the brink, a bridge will grow before your way as it did upon Kehama's triumphal entrance into Padalon. (STM 159)

On one level, this comparison describes a logical gap in terms of its geographical analogue. But the metaphor also suggests that Kehama's self-sabotaging pursuit of global rule resembles Montesinos's, both texts portraying an overeager imperialist whose designs threaten to collapse under the weight of their ambition. Equally relevant to my claim that these works advance a blended vision of Hinduism and the Industrial Revolution is the fact that both portray imperial power emerging from the intersection of paganism and technology, as the passage in Kehama that More references here suggests:

Darting from the Swerga's heavenly heights,

Kehama, like a thunderbolt, alights.

In wrath he came, a bickering flame

Flash'd from his eyes which made the moonlight dim,

And passion forcing way from every limb,

Like furnace-smoke, with terrors wrapt him round. (Kehama 194, my emphasis)

While in 1829 Southey looks back on his earlier poem addressing Hinduism to aestheticize the impact of the manufacturing system, that very text mentions industrial technology to evoke the 


\section{Romanticism on the Net \#68-69 (Spring-Fall 2017). Special issue on Robert Southey. Guest-edited by Tim Fulford (De Montfort University) and Matthew Sangster (University of Glasgow)}

power of Indian ritual. Reading his own epic of Hinduism in the spirit of a "hermeneutics of suspicion" (Ricoeur, Freud 32), Southey thus recasts Kehama as an allegory of entwined imperial and industrial networks.

14. Thus the Colloquies suggests an allegorical reading of The Curse of Kehama, the tale of a maniacal Vedic king bent on conquering the cosmos. In a metaphor conflating thermodynamic and divine energy, Southey implies that the ashvamedha, which produces enough tapas or sacred heat to fuel Kehama's bid for global rule, stands in for the steam engine, a central innovation of the age. Read alongside the Colloquies, The Curse of Kehama thereby explores the theological implications of this new species of power, aestheticizes the connection between imperial and technological systems, expresses the imaginative significance of twinned manufacturing novelties - the steam engine and coke smelting - and concretizes the opaque moral and poetic properties attaching to industrial power by depicting it in reference to the minutiae of Hindu religion so far as Southey understood it.

15. Southey thus implies that the Industrial Revolution inspired a wider range of poetic idioms than scholars tend to realize. Raymond Williams describes the familiar poetic response to technology, writing that those who invoke "Nature's dread protection" (Wordsworth 315) against the traumas of manufacturing express what he calls a "structure of feeling" that predominates in Romantic attempts to understand the meaning of this system. For Williams this term describes "a kind of feeling and thinking" bound up with "social and material" conditions that produce in tandem a given epoch's "quality of social experience and relationship" (Marxism 131), meaning that the Romantic-era constellation of moods, fears, and aesthetic susceptibilities emerges in dialogue with "capitalism, in its specific forms of urban and industrial development" (Country 37). That writers of the era valorized nature in the face of social upheaval is perhaps the single most familiar idea associated with British Romanticism. Describing the elegiac mood presiding over such descriptions, Williams writes of "that very powerful myth of modern England in which the transition from a rural to an industrial society is seen as a kind of fall" (96), identifying from these historical and poetic materials a "Romantic structure of feeling - the assertion of nature against industry and poetry against trade" (79). But while he holds that this myth of a collective lapse is the "main source for the structure of feeling" (96) that prompts poets to see new meanings in agrarian hamlets and haunting 


\section{Romanticism on the Net \#68-69 (Spring-Fall 2017). Special issue on Robert Southey. Guest-edited by Tim Fulford (De Montfort University) and Matthew Sangster (University of Glasgow)}

landscapes, Southey's portrayal of the manufacturing system in the Colloquies and Kehama implies a distinct and less familiar network of tastes and presuppositions. Technology here occasions not a spiritual lapse, but rather a kind of conversion to pagan social forms and mental states - throughout Colloquy VII industrial-era Britons appear in the guise of acolytes of Indian religion-while the moods evoked in these texts reflect an evolving drama between colonial margin and metropolitan center more than what Williams calls "the altering relations of country and city" (292).

16. Southey's reliance on metaphor to describe this matrix of thought and feeling is not incidental. Instead, I claim that metaphor acts to give shape to the moods that Williams' model describes, serving as the conduit through which structures of feeling enter discourse. Williams writes that a given structure begins existence "in an embryonic phase" (Marxism 131) only, barely discernable on the horizon of collective thought and thus "distinct from other social semantic formations which ... are more evidently ... available" (133). Since Williams's structures exist "at the very edge of semantic availability" (133) and require "new semantic figures" (133) to give them form, a theory describing metaphor as a "semantic innovation, or semantic event" (Ricoeur, Rule 114) suggests that this trope plays a role in the process by which given structures become tangible. As Ricoeur writes, "it is as though ... tropes gave to discourse a quasi-bodily externalization. By providing a kind of figurability ... tropes make discourse appear" ("Metaphorical" 229). Thus the "new semantic pertinence" (Rule 272) created through metaphor substantiates the moods, affects, perceptions, and aesthetic modalities that any such structure comprises (perhaps its power to crystallize unknown and "pre-emergent" [Williams, Marxism 132] sensibilities is what inspires Donald Davidson to conjecture that "metaphor is the dream work of language" [200]). Through descriptions of classes as castes, engines as ashvamedhas and political economy (more precisely, the entwined pressures of market forces and government policy) as "Hindoo mythology" itself, Southey gives shape to an alternative structure of feeling that reflects the international identity of Romantic machines and techniques.

17. As Colloquy VII begins winding to a close, the ghost of Sir Thomas reaffirms the role of metaphor both to shape new sensibilities and to "extend language to say what cannot be said in terms of literal meaning alone" (Henle 95), allowing readers thereby to glimpse the magnitude of the Industrial Revolution: 


\section{Romanticism on the Net \#68-69 (Spring-Fall 2017). Special issue on Robert Southey. Guest-edited by Tim Fulford (De Montfort University) and Matthew Sangster (University of Glasgow)}

Society has its critical periods, and its climacterics [...] and at all seasons it is liable to its influenzas and its plagues. This is one of its grand climacterics. A new principle,..a novum organum has been introduced,..the most powerful that has ever yet been wielded by man. If it was first Mitrum that governed the world, and then Nitrum, both have had their day [...] Steam will govern the world next,...and shake it too before its empire is established. (STM 198-199)

Bacon's Novum Organum famously reimagines idolatry to describe the obstacles preventing an objective examination of the natural world, idols of the tribe, cave, marketplace, and theater coming to represent the "false notions that have hitherto occupied the human understanding, and lie deep-seated ... beset[ing] men's minds" (Bacon 29). But while this quintessential pagan object "plugs the gaps in the literal vocabulary" (Black 69) available to early theorists of the scientific method, Hinduism, the quintessential pagan religion, signifies allegorically throughout The Curse of Kehama, fostering a new sensibility. As such I claim that the poem exposes industrialism to a "speculative mode of discourse" that "finds its condition of possibility in the ... metaphorical utterance" (350). Describing one network in reference to its unlikely analog on the far side of Britain's growing empire creates an "innovation in meaning" that frames technology as a new species of art object harboring unknown rhetorical power, or what Williams calls "radically new semantic figures" (Marxism 135). Thus Kehama explores the moral, theological, and poetic properties of the Industrial Revolution.

II.

18. A deliberately extravagant poem, The Curse of Kehama is premised on the imperial ambitions of the titular rajah, who usurps the gods using divine energy leveraged through an audacious series of sacrifices. Standing in Kehama's way are a pious human named Ladurlad and his daughter Kailyal, a "glendoveer" or Indian angel named Ereenia, a host of Hindu gods including Indra, Ganesh, and Shiva, as well as many less familiar deities-Marriatly, Casyapa, Camdeo, Pollear - and a small fleet of sentient vehicles that shuttle the human portion of this crew across the cosmos. Kehama and his antagonists finally arrive in Padalon where the rajah, now a newly-minted deity thanks to the power of the ashvamedha, defeats Yamen, a kind of infernal prison warden. Having dispatched the coalition of forces allied against him, Kehama drinks a liquor of immortality meant to bestow eternal life in which to enjoy his newly won 


\section{Romanticism on the Net \#68-69 (Spring-Fall 2017). Special issue on Robert Southey. Guest-edited by Tim Fulford (De Montfort University) and Matthew Sangster (University of Glasgow)}

omnipotence. But this final act is his undoing, the drink instead forcing the king to prop up Yamen's throne in hell for the rest of time.

19. Critics have long noted the story's strange immoderation. Convinced of Southey's immersion in pagan logic, Walter Scott marveled at the poem's authenticity, writing that its power stemmed "from the uncommon art with which [Southey] has maintained the character of a poet of Hindostan," so that the "language, the sentiments, are Oriental" and the text is "composed of the very materials" (180) of the east. Suggesting more ominously that the poem acts as a kind of Trojan horse that might smuggle paganism into Britain, John Foster warned that Kehama "engage[s] our complacency in such a fictitious economy of divine and human beings as, if it could be real, would constitute the negation or extinction of [Christianity]" (491). It was "the Paganism of the whole theology of this poem" that he and others found so unnerving, a view further suggesting the relevance of the Colloquies to Kehama. If idols can be made to suggest the poetry of machines, a poem defined by "genuine and formal heathenism" is uniquely positioned to aestheticize the Industrial Revolution. Just as Indian wealth propels Britain's techno-imperial enterprise, Kehama's paganism supplies the raw discursive material through which Southey fashions a poetics of industrial technology.

20. The prevailing acceptance of Edward Said's claim that "the Orient was almost a European invention" (1), however, means that Kehama now seems less likely to reveal "the religion of the Hindoos" than to encode the values of its day, the poem thus appearing "more valuable as a sign of European-Atlantic power over the Orient than it is as a veridic discourse about the Orient" (6). Advancing under the banner of these presumptions, much contemporary scholarship sees an ambivalence within the poem symptomatic of imperial discourse more generally. Noting that conflicted imperial attitudes inform the poem's very structure, Balachandra Rajan writes that "the preface begins with a resounding dismissal of the very mythology on which the poem is based" (139), so that "the extent to which Southey goes to distance himself from The Curse of Kehama is the most striking feature of the poem." Carol Bolton meanwhile accounts for "the irregularities and discontinuities that fracture its coherence" (207) by noting that "Southey incorporated both the 'Orientalist' and the 'Anglicist' viewpoints in his poem" (211), meaning that enthusiasm vies with contempt for Indian culture throughout. Since these attitudes are incommensurable, the text "is similarly divided by this political fault-line" (211). 


\section{Romanticism on the Net \#68-69 (Spring-Fall 2017). Special issue on Robert Southey. Guest-edited by Tim Fulford (De Montfort University) and Matthew Sangster (University of Glasgow)}

21. These and other readings that reduce "the paganism of the whole theology of the poem" to symptoms of imperial ambivalence, however, are ill-positioned to recognize that its dissonance also reflects distinctions within Hinduism itself - an argument that promises to shed light both on the poem's strange divisions, and on how its religious material implies a poetics of technology. On the one hand, Ladurlad, Kailyal, Ereenia, and the gods that help them act in line with a bhaktic worldview. Instead of using the coercive power of sacrifice to manipulate the gods after Kehama's fashion, Kailyal and Ladurlad piously petition divinities with whom they enjoy a measure of intimacy, thereby reflecting a bhaktic devotional idiom that informs descriptions of everyone who stands against Kehama. Unlike the prevailing theology of the Vedas, which in my reading aligns with Kehama, "the important factor in bhakti is its power to bind together the human and the divine, not in bonds of duty or domination, but in a relationship of loving protection on the divine side and loving service on the human" (Matchett 142). After Kehama's apotheosis, Ladurlad and Kailyal thus return defeated to their agrarian home, a place "so like a temple" that there, "a pious heart's first impulse would be prayer" (Kehama 134). In this space of "reflective, thoughtful piety" (Matchett 140) Ladurlad duly presents,

An offering, not of ghee, or fruit, or rice,

Flower-crown, or blood; but of a heart subdued,

To her who, on the secret throne reclin'd,

Amid the milky sea, by Veeshnoo's side,

Looks with an eye of mercy on mankind.

There Voomdavee beholds this lower clime,

And marks the silent sufferings of the good,

To recompense them in her own good time. (Kehama 137)

Father and daughter are not "on a Christian mission through a world of superstition" (Bolton 212), but they do exemplify attitudes toward the divine closer to Christian models of worship than Kehama's. While Bolton writes that "the religious rituals of Kehama dominate the poem" (211) because Southey admires Hindu mythology while despising its popular expressions, I contend instead that the emphasis afforded sacrifice suggests a preoccupation with the Industrial Revolution, which finds expression in reference to the Vedic Kehama exclusively. 
22. Sacrificing horses to produce the divine energy called tapas, Kehama indeed behaves in accord with a Vedic worldview, delineated between ca. 1500 and ca. 500 BCE (Witzel 68). Vedic theological precepts can be discerned whenever Kehama appears, as well as in the poem's preface, where Southey writes that Hindu "prayers, penances, and sacrifices, are supposed to possess an inherent and actual value, in no degree depending upon the disposition or motive of the person who performs them" (Kehama vii). Rajan admits that this "interpretation can be justified, given a resolutely literal reading" (150) of the Vedas. However, he soon adds that "to discourage such a reading it should be sufficient merely to point to the creation hymn in the Rigveda $(\mathrm{X}, 129)$... which as befits a meditative poem, is ... a reading of its readers. The Vedas," he concludes, "call for a reading that is literary rather than literal, but literal readings are less difficult and more persuasive for those seeking to devalue Hindu civilization."

23. Yet scholars of Hinduism today favor readings of the Vedas more in line with Southey than with Rajan, surprising as this may sound. Carl Olson writes that "in the Rig Veda, everything that exists is created by means of the sacrifice" (45), adding that "it is also important for the participants to trust in the automatic result of the sacrifice" (46). Just as Southey claims that these petitions are "drafts upon Heaven, for which the Gods cannot refuse payment" (Kehama vii), Olson explains that "within such a system, priests intend for the ritual to produce results automatically" (Olson 46). Kehama's affiliation with the Brahmins who oversee the ashvamedha and whose Juggernaut is the subject of section 14 reflects the prevailing view that "the Vedic priests" were those who "attempted to create a closed system that they could control and direct by means of ritual" (46). In fact, the poem's narrative momentum springs from the principle that "what is most important in the later Vedic period is the sacrifice itself" (Davis 11). Kehama's bid for power reveals a Vedic "belief in the efficacy of prayer and sacrifice because the priests claim to control the gods and capture them in the net of sacrifice and make them do their bidding," meaning that "sacrifice is superior to gods and it is not to gods but to sacrifice men owe their existence and preservation" (Gupta 85).

24. This comparison between technology and sacrifice produces one of the poem's "semantic innovations" (Ricoeur, Rule 187), a "gestalt switch" (Johnson 30) that presents a fused image of technology-as-Vedic power. If in Vedic thought "the sacrifice is built into the order of things" so that "to know the sacrifice is to know and control the inner workings of the universe"-even 


\section{Romanticism on the Net \#68-69 (Spring-Fall 2017). Special issue on Robert Southey. Guest-edited by Tim Fulford (De Montfort University) and Matthew Sangster (University of Glasgow)}

to the point that "the ancient Vedic sacrifice becomes an explanatory model for the structure of the cosmos" (Olson 45) - this metaphor frames industrial engineering in similarly cosmic terms as it "selects, emphasizes, suppresses and organizes features of" new technology "by implying statements about it that normally apply to" (Black 78) idolatrous religion. Kehama thus suggests that technology, too, afforded "know[ledge] and control [of] the inner workings of the universe," registering how for the first time in history the infinite storehouse of solar energy had been unlocked and siphoned to power various devices. As Henri Bergson writes, "machines which run on oil or coal ... and which convert into motion a potential energy stored up for millions of years, have actually imparted to our organism an extension so vast, have endowed it with a power so mighty, so out of proportion to the size and strength of that organism" that the engineering feat represents "the greatest material success of man on the planet" (309). Indian religion supplies the reference point for this staggering advance, allowing Southey to evoke the many-faceted identity of the Industrial Revolution, or what Jeremy Stolow calls "the cosmological, ethical, and theological dimensions of technology itself as a force of historymaking and as a mode of being-in-the-world" (10). Here, Hinduism inflects a vision of engineering that emerges at the advent of technological modernity itself.

25. Southey continues to draw from Vedic precepts in his depiction of the ashvamedha, a ritual performed on behalf of kings of Indian antiquity in which a horse wandered at will for one year before being sacrificed. The king enjoyed terrestrial and spiritual gains as the stallion was killed, claiming whatever land the horse had strayed into even while producing divine heat through the sacrifice itself. Yet repeating the act one hundred times would also raise him to the status of a divine being: Indra, for example, "prides himself on having performed a hundred horse sacrifices" (Doniger, Origins 88). Kehama's progress when the poem starts ("Nine and ninety steeds have bled; / One more the rite will be complete" [Kehama 74]) reflects this expropriation of new land as well as the ritual's power to create gods from men. Before the poem begins, Kehama:

went on

Conquering in irresistible career,

Till his triumphant car had measured o'er

The insufficient earth, and all the kings

Of men received his yoke; then had he won 


\section{Romanticism on the Net \#68-69 (Spring-Fall 2017). Special issue on Robert Southey. Guest-edited by Tim Fulford (De Montfort University) and Matthew Sangster (University of Glasgow)}

His will, to ride upon their necks elate,

And crown his conquests with the sacrifice

That should, to men and gods, proclaim him Lord

And Sovereign Master of the vassal World,

Sole Rajah, the Omnipotent below. (Kehama 70)

Southey seems to realize that a Vedic "king has to be very powerful before attempting [the ashvamedha] because he had to have the power to annex any land the horse might wander into" (Doniger, Hindus 144). Thus Kehama's trajectory across the poem reflects the fact that in "Vedic scripture, there is not a wide gap between gods and human beings" (Olson 41).

26. By using Vedic sacrifice to signify the steam engine allegorically, Southey explores the industrial turn away from equestrian power. Thomas Savery, who in 1698 built "the first practicable device for the conversion of thermal energy into work" (Landes 100), was also the first to imagine an engine's output in reference to the horses that it replaced. He reasoned that "an engine may be made large enough to do the work required in employing eight, ten, fifteen, or twenty horses to be constantly maintained and kept for doing such a work" (Savery 26). Thus the steam engine and the ashvamedha alike foreground the animal on which their capacity to generate power is premised ("horsepower" as a unit of measurement did not come into use until 1806, when it was made to represent 745.7 watts). The absorption of organic being into mechanical process signaled by the comparison suggests that "It is precisely the availability of inanimate sources of power that has enabled man to transcend the limitations of biology and increase his productivity a hundred times over" (Landes 98). Like the pioneering industrialists to whom he is implicitly compared, Kehama accesses "inanimate sources of power" in order to "transcend" terrestrial limitations. Examining with Michael Franklin "what Southey does get right about Hinduism" (267) thus means asking how Romantic authors also render technical systems in poetic terms. Beyond fashioning a cosmic identity for technology and exploring how the concept of horsepower was rapidly evolving, this portrayal of Vedic industrialism also suggests that steam power appeared to close the gap between human and super-human magnitudes of control over the natural world. As Michael Adas writes:

Scientific discoveries and technological breakthroughs made it more and more possible for Europeans to translate anthropocentric presuppositions into the actual mastery of previously untapped sources of animate and inanimate energy and into an 


\section{Romanticism on the Net \#68-69 (Spring-Fall 2017). Special issue on Robert Southey. Guest-edited by Tim Fulford (De Montfort University) and Matthew Sangster (University of Glasgow)}

unparalleled capacity to reshape the natural environment to suit human needs and desires. (Adas 210)

Questions regarding the Vedic identity of the titular king thereby intertwine with what Heidegger names "the question concerning technology" (Heidegger), which investigates a shift occurring throughout industrialization whereby humans instrumentalize the natural world, reframing it as a repository of potential energy ripe for exploitation.

27. Alongside this gestalt of engine and sacrifice emerging through descriptions of the ashvamedha, there also exists a blend of steam and tapas, the divine heat produced from ritual and meditation. As the ashvamedha nears completion, Southey writes that "the steam of that portentous sacrifice / Arose to Heaven" (Kehama 70), signaling the beginning of Kehama's apotheosis. Yet by 1810 the definition of steam as the "vapor of boiling water used to drive an engine" had existed for more than a century, becoming so entwined with the factory system that "steam age" as a shorthand for its supremacy entered use in 1828. The accurate word in this context, "smoke" was no less distinct from steam in this era than it is in ours. Claiming that Southey "never quite understood about tapas" (265) because he fails to portray it in spiritual and ascetic terms, Franklin concludes that the poem's emphasis on sacrifice instead betrays a "desire to make this Hindu concept monstrous, the product of a dangerous (and dangerously Catholic) mingling of religious (Brahmanical) and monarchical power, facilitating only selfish and evil power-seeking" (266). Yet the poem's descriptions of tapas as a mechanical conduit of willpower portray it with some accuracy - Sarvepalli Radhikrishnan writes that "the religion of the Yajur-Veda is a mechanical sacerdotalism" (123), Doniger mentions "the symbolism and mechanism of Vedic ritual" (Rig Veda 3) and Robert Inden, paraphrasing Arthur Llewyn Basham, describes "the sacrifice as a form of false technology" (99) — even as they aestheticize the sublime and unstable power of steam. In both Kehama and the Colloquies "steam" signifies access to unstable reserves of power, so that anyone witnessing Kehama's tapas-fueled apotheosis would be led to predict with Montesinos that "steam will govern the world next" (STM 199). Steam power thus brings radically unstable dominion within reach of Kehama and Britain alike:

Steam, said I to Sir Thomas when he visited me next, has fearfully accelerated a process which was going on already but too fast. Could I contemplate the subject without reference to that Providence which brings about all things in its own good 


\section{Romanticism on the Net \#68-69 (Spring-Fall 2017). Special issue on Robert Southey. Guest-edited by Tim Fulford (De Montfort University) and Matthew Sangster (University of Glasgow)}

time, I should be tempted to think that the discovery of this mighty power had come to us, like the possession of great and dangerous wealth to a giddy youth, before we knew how to employ it rightly. (STM 200-201)

28. Throughout the poem, these depictions of pagan engineering merge the Indian gothic, which casts the subcontinent as a "land of religious nightmare" (Rudd 12), with the industrial sublime, wherein "vast machinery" compels "onlookers to respect the power of the corporation and the intelligence of [the] engineers" (Nye 126) who make harnessing such energy possible. The thrill of controlling such mighty forces combines with the thrill of helplessness in the midst of strange rites and elaborate religious systems, causing sensations of impotence and empowerment to oscillate in tandem. Yet these passages are not Southey's first foray into the technological sublime. Assuming the guise of a Spaniard presenting a travelogue of his wanderings in Britain, he shows in Letters from England (1807) how machines have transformed Birmingham, striking similar notes of overawed but ambivalent admiration. "Don Manuel Alvarez" reports that "I am still giddy, dizzied with the hammering of presses, the clatter of engines, and the whirling of wheels" (210), before shifting to a more sinister tone: "my head aches with the multiplicity of infernal noises, and my eyes with the light of infernal fires." Delirium and dismay lapse into pity_- "my heart also [aches], at the sight of so many human beings employed in infernal occupations"-while this feeling gives way in turn to what Herbert Grabes calls "the aesthetic of the strange" (xxi), a bordering sensation, as when Southey beholds workers transformed by industrial processes: "Some I have seen with red eyes and green hair; the eyes affected by the fires to which they are exposed, and the hair turned green by the brass works" (192). This sequence of responses to exotic devices recalls that the era's appetite for the sublime sharpened as Britain assimilated new technologies: as David Nye notices, a taste for "the sublime ... reemerged in the eighteenth century in tandem with the ... advent of industrialization" (282).

29. And yet Southey here merely echoes a prior response to manufacturing that also merges pity, estrangement, and awe. Three years earlier, S. T. Coleridge had written to Southey describing the awesome processes witnessed on his own tour of the Portsmouth Block Mills. Coleridge was, 


\section{Romanticism on the Net \#68-69 (Spring-Fall 2017). Special issue on Robert Southey. Guest-edited by Tim Fulford (De Montfort University) and Matthew Sangster (University of Glasgow)}

lucky enough to be present at a Heat, i.e. at the welding of a huge Faggot of small latten of red-hot Iron into the Shafts of the Anchor of a man of war. It was truly sublime-the enormous Blaze, the regular yet complex intertwisted strokes of between 20 and 30 men, with their huge Flail-hammers, the astonishment how they could throw them about, with such seeming wildness without dashing out each other's brains, and how they saved their eyes amidst the shower of sparks - the Iron dripping like a millwheel from the intense white heat-verily it was an unforgettable scene. (Coleridge 74)

As in the Letters, an astonished first impression rapidly gives way to concern for the workers' welfare, followed quickly by a new shade of dismay as Coleridge witnesses a bizarre transformation brought on by exotic machinery: "The poor men are pitiable slaves_-from 4 in the morning they work till 9 at night, and yet are payed less than any other in the yard. They all become old men in the prime of manhood. So do the rope-makers who yet only work from 7 till noon."

30. But as he goes on to describe the room where these men labor, Coleridge reveals how much this letter may have influenced a poetics of manufacturing in Southey. "The rope-room is a very low broad room," he writes, "of a length far too great for the eye to see from one end to the otherit gave me a grand idea of an Hindustan Cavern. A fire machine has been lately introduced." At least two features here are worth noting. First, the sublime power and radiance of industrial technology compel an identification with the religious other in a prelude to the discourse of conversion that Southey would continue to develop in the Colloquies and Kehama (Coleridge almost surely has in mind the Caverns of Elephanta, a popular Indian tourist attraction and bygone site of worship). Next, throughout his letter Coleridge depicts such dreadful power that the mood begins to shade into the apocalyptic sublime, which witnesses "divine forces virtually breaking through nature" (Paley 2).

31. Echoing Coleridge, Southey blends the industrial and the apocalyptic sublime in Kehama, displacing a borderline-religious awe toward technology to describe the lavish spectacles of religious energy that punctuate the poem. At Kehama's opening, as spectators pour into the streets to witness the rajah's funeral for his rapacious son Arvalan, Southey describes the first of several show-stopping set pieces: 


\section{Romanticism on the Net \#68-69 (Spring-Fall 2017). Special issue on Robert Southey. Guest-edited by Tim Fulford (De Montfort University) and Matthew Sangster (University of Glasgow)}

Vainly, ye blessed twinklers of the night,

Your feeble beams ye shed,

Quench'd in the unnatural light which might out-stare

Even the broad eye of day;

And thou from thy celestial way

Pourest, O Moon, an ineffectual ray!

For lo! Ten thousand torches flame and flare

Upon the midnight air,

Blotting the lights of heaven

With one portentous glare.

Behold the fragrant smoke in many a fold,

Ascending floats along the fiery sky,

And hangeth visible on high

A dark and waving canopy. (Kehama 2)

That 10,000 torches might blot out "the lights of heaven" borders on the hyperbolic. But the notion that this description signals a buried agenda - that "this literal surface suggests a peculiar doubleness of intention" (Fletcher 7), in Angus Fletcher's phrasing-grows more likely when Southey recycles this language later in the poem. When the Brahmans of "Juger-naut" kidnap Kailyal, the narrator addresses the sky to protest that it has been outshone again:

And thou, O Moon! Whose quiet light serene

Filleth wide heaven, and bathing hill and wood,

Spreads o'er the peaceful valley like a flood

How have they dimm'd thee with the torches glare

Which round yon moving pageant flame and flare,

As the wild rout, with deafening song and shout,

Fling their long flashes out,

That, like the infernal lightnings, fire the air. (146)

In both scenes, popular religious spectacle expresses a malign agenda, sky and "powerful valley" being outshone and engulfed by a radiance that threatens to destroy a scene of natural tranquility. Any doubt that these similarities are insignificant vanishes as the same language appears yet again, in the passage that the ghost of Thomas More would later reimagine as a metaphor for runaway techno-imperial power: 
darting from the Swerga's heavenly heights,

Kehama, like a thunderbolt, alights.

In wrath he came, a bickering flame

Flash'd from his eyes which made the moonlight dim,

And passion forcing way from every limb,

Like furnace-smoke, with terrors wrapt him round. (194)

Unnatural light obscures the moon a third time, the "bickering flame" stemming now from Kehama's eyes and expanding throughout his body, which has been enshrouded by a divine energy that resembles "furnace-smoke."

32. On their own terms, these descriptions are simply implausible. Even should 10,000 torches manage to obscure the stars during Arvalan's funeral, it remains unclear how revelers following the Juggernaut's mobile tableaux might produce the same effect. Meanwhile in subterranean Padalan, "the World below," there presumably exists no moon that Kehama's smoke could obscure. But if these passages are merely semi-coherent on their own terms, they double as precise ekphrases of Philip James de Loutherbourg's Coalbrookdale by Night (1801): 


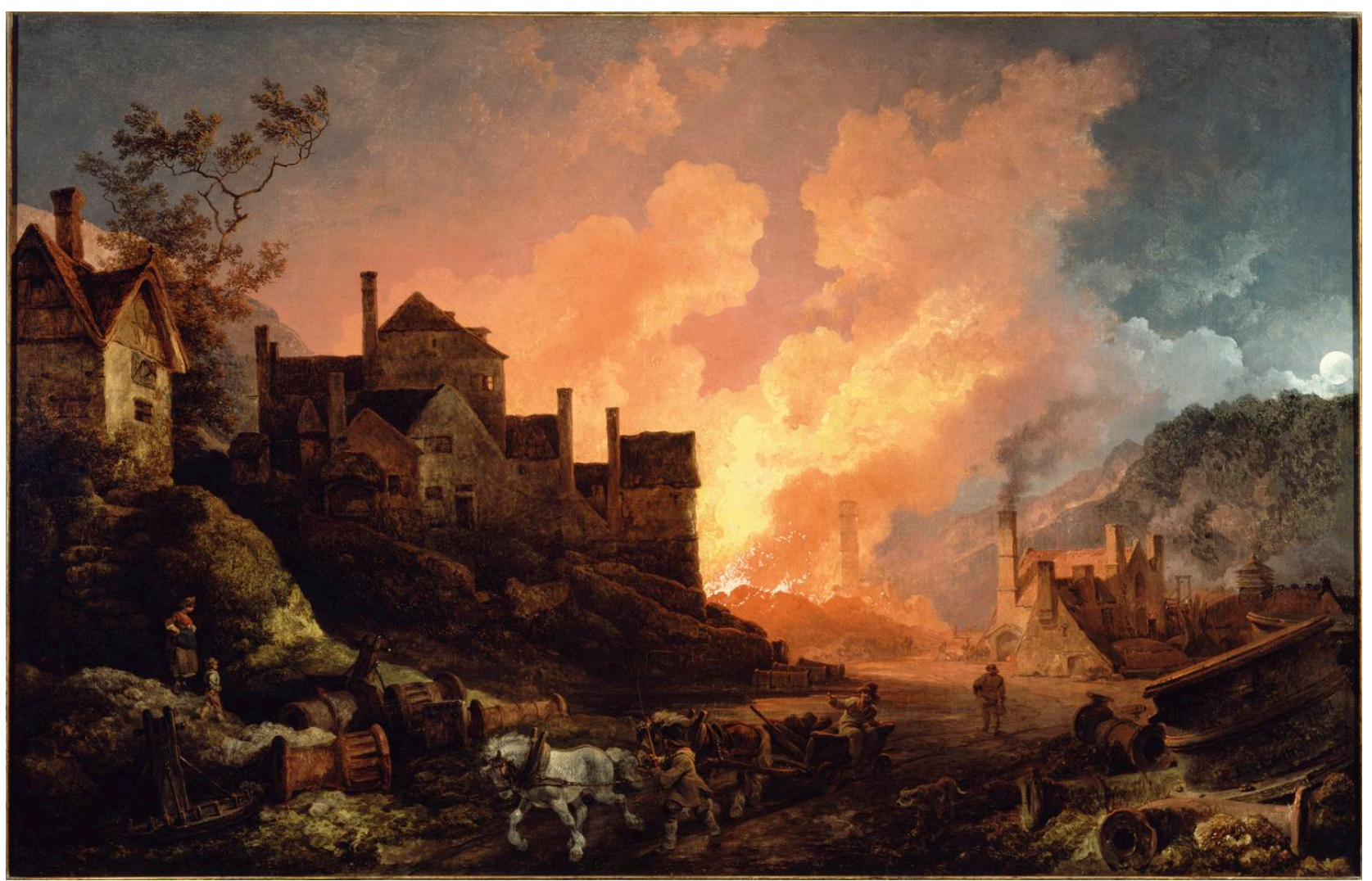

Figure 1: Colebrookedale by Night, Philip Jacques du Loutherbourg, 1801. Science Museum. Released under a Creative Commons Attribution-NonCommercial-ShareAlike

\section{0 license.}

The pictorial exemplar of the industrial sublime, this painting depicts the site where Abraham Darby first smelted iron using coke fuel in 1702. Here, the "Bedlam furnaces"-larger than their precursors because coke sustains a greater fire at hotter temperatures than fuel derived from vegetable matter-obscure the night sky with their gloomy radiance. The thickening exhaust is both sublime and "unnatural," given the heavy refinement needed to turn mineral coal into coke. Meanwhile at the picture's rightmost edge, the "dimm'd" moon's "quiet light serene" is no match for the "flash" of the "furnace-smoke," which "fires the air," engulfing "hill and wood" and "peaceful valley" in an "infernal" glow. The precise applicability of these descriptions to the iconic industrial image - the painting could double as a visual portrayal of religious rites in Kehama-shows that Southey displaces Coalbrookdale into these showstopping spectacles of Vedic religious power. Given that De Loutherbourg "had by 1789 ... begun to paint overtly apocalyptic subjects" (Paley 14), Southey in fact brings Coalbrookdale full circle, returning the image to the kind of religious setting that the painter drew upon to 


\section{Romanticism on the Net \#68-69 (Spring-Fall 2017). Special issue on Robert Southey. Guest-edited by Tim Fulford (De Montfort University) and Matthew Sangster (University of Glasgow)}

compose it. Kehama thus displaces into moments of Vedic power a scene of industrial might that itself references a visual rhetoric of apocalyptic awe, implying that spectacles of mechanical power also suggest "a threshold beyond the natural sublime" whereby, through the expenditure of great energy, a "veil, although not raised, trembles" (11).

33. In this allegory the steam age amounts to a kind of conversion to pagan ways of living and feeling. The Colloquies and Kehama thus appear to crystallize an unfamiliar constellation of moods and aesthetic sensibilities born from the manufacturing system. Other Romantic texts addressing technology bear out the conjecture that a variant idiom exists, as when Wordsworth describes a cotton factory in Book VIII of The Excursion as:

a temple, where is offered up

to gain, the master Idol of the realm,

perpetual sacrifice" (Excursion VIII 83-85),

or when East India Company chaplain Claudius Buchanan figures the Indian god Juggernaut as a "ponderous machine" (18). These depictions may influence how we imagine the legacy of the Romantic response to the Industrial Revolution. A structure of feeling divergent from the more familiar program celebrating the natural world suggests that models of subjectivity derived from manufacturing and emerging global systems also condition Romantic poetics. Reading Kehama against this sensibility in the same way that The Prelude (1805) exemplifies "the assertion of nature against industry," for example, finds Southey describing glorified states of being ensuing from what Walter Benjamin has called mechanical reproducibility, rather than the mind's capacity to assimilate the wonder of the natural world. Given that the mills described in Coleridge's missive are "the earliest industrial example of a linear and continuous assembly process" (“Assembly Line," Wikipedia), Kehama's repetitive sacrifices - one every day for one hundred days, and then god-begin to appear as a kind of assembly-line apotheosis. Like the metaphors that populate the Colloquies and Kehama, this trope registers an emergent global network as the occasion for new poetic sensibilities. 


\section{Romanticism on the Net \#68-69 (Spring-Fall 2017). Special issue on Robert Southey. Guest-edited by Tim Fulford (De Montfort University) and Matthew Sangster (University of Glasgow)}

\section{Works Cited}

Adas, Michael. Machines as the Measure of Men: Science, Technology, and Ideologies of Western Dominance. Ithaca: Cornell University Press, 1989.

“Assembly line." Wikipedia, The Free Encyclopedia. Wikimedia Foundation, Inc. 24 May 2018, https://en.wikipedia.org/wiki/Assembly_line.

Bacon, Francis. "On the Idols, the Scientific Study of Nature, and the Reformation of Education." Philosophy of Technology: The Technological Condition, edited by Robert C. Scharff and Val Dusek, Oxford: Blackwell Publishing, 2003, pp. 25-37.

Bergson, Henri. The Two Sources of Morality and Religion. Translated by R. Ashley Audra and Cloudsley Brereton, Indiana: University of Notre Dame Press, 1977.

Black, Max. "Metaphor." Philosophical Perspectives on Metaphor, edited by Mark Johnson, Minneapolis: University of Minnesota Press, 1981.

Bolton, Carol. Writing the Empire: Robert Southey and Romantic Colonialism. London: Pickering and Chatto, 2007.

Buchanan, Claudius. Christian Researches in Asia: With Notices on the Translation of the Scriptures into the Oriental Languages. New York: Richard Scott, 1812.

Coleridge, Samuel Taylor. Coleridge's Writings Volume 5: On the Sublime. Edited by David Vallins, New York: Palgrave Macmillan, 2003.

Davidson, Donald. "What Metaphors Mean.” Philosophical Perspectives on Metaphor, edited by Mark Johnson. Minneapolis: University of Minnesota Press, 1981, pp. 200-220.

Davis, Richard H. "Introduction: A Brief History of Religions in India." Religions of India in Practice, edited by Donald S. Lopez Jr., Princeton: Princeton University Press, 1995, pp. 3-52.

Doniger, Wendy. The Hindus: An Alternative History. Oxford: Oxford University Press, 2009. (Hindus).

---. "Introduction." The Rig Veda: An Anthology, translated and edited by Wendy Doniger, New York: Penguin Books, 1981, pp. 11-21. (Rig Veda).

---. The Origins of Evil in Hindu Mythology. Berkeley: University of California Press, 1976. (Origins).

Fletcher, Angus. Allegory: The Theory of a Symbolic Mode. Princeton: Princeton University Press, 2012.

Foster, John. Critical Essays Contributed to the Eclectic Review Vol. I. Edited by J. E. Ryland, London: Henry G. Bohn, 1856. 


\section{Romanticism on the Net \#68-69 (Spring-Fall 2017). Special issue on Robert Southey. Guest-edited by Tim Fulford (De Montfort University) and Matthew Sangster (University of Glasgow)}

Franklin, Michael J. “'Drafts upon Heaven': Robert Southey, Tapas, and the 'monstrous fables' of Hinduism and Romanticism.” European Romantic Review, vol. 22, no. 2, 2011, pp. 257-276.

Geertz, Clifford. The Interpretation of Cultures. New York: Basic Books, 1973.

Grabes, Herbert. Making Strange: Beauty, Sublimity, and the (Post)Modern 'Third Aesthetic.' Translated by Marc Colavincenzo, Tübingen \& Basel: Francke, 2004.

Gupta, Uma. Materialism in the Vedas. New Delhi: Classical Publishing Company, 1987.

Heidegger, Martin. The Question Concerning Technology and Other Essays. Translated by William Lovitt, New York: Harper Torchbooks, 1977.

Henle, Paul. "Metaphor." Philosophical Perspectives on Metaphor, edited by Mark Johnson, Minneapolis: University of Minnesota Press, 1981, pp. 83-104.

Houtman, Dick, and Brigit Meyer. "Introduction: Material Religion-How Things Matter." Religion and the Question of Materiality, edited by Dick Houtman and Brigit Meyer, New York: Fordham University Press, 2012, pp. 1-23.

Inden, Robert. Imagining India. Indianapolis: Indiana University Press, 1990.

Johnson, Mark. "Introduction: Metaphor in the Philosophical Tradition.” Philosophical Perspectives on Metaphor, edited by Mark Johnson, Minneapolis: University of Minnesota Press, 1981, pp. 347.

Landes, David S. The Unbound Prometheus: Technological Change and Industrial Development in Europe from 1750 to the Present. Cambridge: Cambridge University Press, 2003.

Makdisi, Saree. Making England Western: Occidentalism, Race, and Imperial Culture. Chicago: University of Chicago Press, 2014.

Marcus, Steven. Engels, Manchester, and the Working Class. New York: Routledge, 2017.

Matchett, Freda. "The Puranas." The Blackwell Companion to Hinduism, edited by Gavin Flood, Oxford: Blackwell Publishing, 2003, pp. 129-143.

Modern, John Lardas. "Thinking about Melville, Religion and Things That Think." Deus in Machina: Religion, Technology, and the Things in Between, edited by Jeremy Stolow, New York: Fordham University Press, 2012, pp. 183-212.

Nye, David E. The American Technological Sublime. Cambridge, MA: MIT Press, 1994.

Olson, Carl. The Many Colors of Hinduism: A Thematic-Historical Introduction. New Brunswick: Rutgers University Press, 2007.

Oxford English Dictionary. www.oed.com.

Paley, Morton. The Apocalyptic Sublime. New Haven: Yale University Press, 1986. 


\section{Romanticism on the Net \#68-69 (Spring-Fall 2017). Special issue on Robert Southey. Guest-edited by Tim Fulford (De Montfort University) and Matthew Sangster (University of Glasgow)}

Radhikrishnan, Sarvepalli. Indian Philosophy. London: Allen and Unwin, 1951.

Rajan, Balachandra. Under Western Eyes: India from Milton to Macaulay. Durham, NC: Duke University Press, 1999.

Richards, I. A. The Philosophy of Rhetoric. Oxford: Oxford University Press, 1936.

Ricoeur, Paul. Freud and Philosophy: An Essay on Interpretation. Translated by Denis Savage, New Haven: Yale University Press, 1970. (Freud).

---. "The Metaphoric Process as Cognition, Imagination, and Feeling." Philosophical Perspectives on Metaphor, edited by Mark Johnson, Minneapolis: University of Minnesota Press, 1981, pp. 228247. ("Metaphoric").

---. The Rule of Metaphor: The Creation of Meaning in Language. Translated by Robert Czerny, Kathleen McLaughlin and John Costello, SJ., London: Routledge Classics, 2003. (Rule).

Rudd, Andrew. Sympathy and India in British Literature, 1770-1830. New York: Palgrave Macmillan, 2011.

Said, Edward W. Orientalism. New York: Vintage Books, 1979.

Savery, Thomas. The Miner's Friend; or, An Engine to Raise the Water by Fire. London: S. Crouch, 1827.

Scott, Walter. The Miscellaneous Prose Works of Sir Walter Scott, Vol. VI. Paris: Baudry's European Library, 1838.

Southey, Robert. The Curse of Kehama. London: James Ballantyne and Co., 1810. (Kehama).

---. Letters from England: By Don Manuel Alvarez Espriella. Edited by Carol Bolton, London: Routledge, 2016.

---. Sir Thomas More; Or, Colloquies on the Progress and Prospects of Society. 2 vols., London: John Murray, 1829. (STM).

Steigler, Bernard. Technics and Time, 1: The Fault of Epimetheus. Translated by George Collins, Stanford: Stanford University Press, 1998.

Stolow, Jeremy. "Introduction: Religion, Technology, and the Things in Between." Deus in Machina: Religion, Technology, and the Things in Between, edited by Jeremy Stolow, New York: Fordham University Press, 2012, pp. 1-22.

Stroumsa, Guy G. A New Science: The Discovery of Religion in the Age of Reason. Cambridge, MA: Harvard University Press, 2010.

Wallbank, Adrian J. Dialogue, Didacticism and the Genres of Dispute. London: Pickering and Chatto, 2012. 
Williams, Raymond. Marxism and Literature. Oxford: Oxford University Press, 1978. (Marxism).

---. The Country and the City. Oxford: Oxford University Press, 1975. (Country).

Witzel, Michael. "Vedas and Upanishads." The Blackwell Companion to Hinduism, edited by Gavin Flood, Oxford: Blackwell Publishing, 2003, pp. 68-101.

Wordsworth, William. "And Is It Among Rude Untutored Dales." The Collected Poems of William Wordsworth, Hertfordshire: Wordsworth Editions, 1994, p. 315.

---. The Excursion. Edited by Sally Bushell, James A. Butler, and Michael C. Jaye, Ithaca: Cornell University Press, 2007. (Excursion). 